DOI : $10.14746 / p p .2014 .19 .1 .21$

\title{
Jacek RAUBO
}

Poznań

\section{Jemen - zapomniany aktor Arabskiej Wiosny}

\begin{abstract}
Streszczenie: Współczesny Jemen jest jednym z kluczowych państw w strukturze geopolitycznej Bliskiego Wschodu. Aczkolwiek w całościowej wizji rewolucji, określanych obecnie jako Arabska Wiosna, które rozlały się w regionie MENA w 2011 r., Jemen pozostaje swoistym zapomnianym aktorem wspomnianych wydarzeń. Jednakowoż, gwałtowny wzrost aktywności organizacji terrorystycznych przede wszystkim AQAP oraz zagrożenie wielce realnym rozpadem państwa na dwie lub więcej części, stał się czytelnym impulsem do rozważenia niejako na nowo sytuacji w Jemenie po ustapieniu prezydenta A. A. Saleha. Stąd też, na wstępie autor artykułu przedstawił tło oraz najważniejsze historyczne problemy i ich implikacje dla obecnego procesu transformacji jemeńskiego państwa. Następnie zaprezentował oraz odniósł się do przebiegu samej Arabskiej Wiosny, w tym najbiedniejszym arabskim państwie regionu. Ostatecznie skoncentrował się na szansach oraz przeciwnościach pokojowego przejścia ze starego reżimu do nowej władzy na przełomie 2012 i 2013 r. Należy podkreślić, że w głównej mierze dla zewnętrznych obserwatorów, istotne jest dostrzeżenie specyfiki jemeńskiego Dialogu Narodowego, jako potencjalnej formy normalizacji sytuacji nie tylko w jednym państwie, ale również swoistego wzoru dla całego, permanentnie niestabilnego regionu. Przy czym potencjalne fiasko politycznych prób rozwiązania sporów w Jemenie będzie sygnałem do nowej fali chaosu oraz wytworzenia olbrzymich baz wypadowych zarówno dla terrorystów, jak i piratów, podobnie jak to miało miejsce w pobliskiej Somalii.
\end{abstract}

Słowa kluczowe: Jemen, Saleh, Arabska Wiosna, Sanaa

\section{Wprowadzenie}

- zeroko opisywana w ostatnim czasie Arabska Wiosna lub raczej cała fala różnego rodzaju rewolucji, specyficznych dla konkretnych warunków społeczno-politycznych państw, w których miały miejsce wystąpienia, diametralnie zmieniła oraz de facto nadal zmienia obraz całego regionu Północnej Afryki oraz Bliskiego Wschodu (MENA - skrót pochodzący z języka angielskiego i oznaczający państwa Bliskiego Wschodu, czyli ME - Middle East oraz Afryki Północnej NA - North Africa). Chociaż od pierwotnych rewolucyjnych zmian z 2011 r. nie minął zbyt duży okres czasu, to należy zauważyć pojawienie się różnych publikacji naukowych, zarówno w języku polskim, jak i angielskim, które odnoszą się do całościowego ujęcia zjawiska w skali regionalnej i światowej. Można podać przykłady takich tytułów jak wydana w Poznaniu The Arab Spring (red. Przybylska-Maszner, 2011) czy też Arabska wiosna. Rewolucja w świecie islamskim (Armbruster, 2012) oraz The Arab Uprising. The Unfinished Revolutions of the New Middle East (Lynch, 2012). Wszystkie rewolucje w regionie MENA składają się na złożony oraz skomplikowany wewnętrznymi charakterystykami poszczególnych państw proces, który trwa nadal i trudno jest określić jego długookresowy wpływ na stosunki mię- 
dzynarodowe. Obecnie dla analityków, zajmujących się problemami regionu MENA, najważniejszą kwestią jest próba określenia scenariuszy rozwoju dalszej sytuacji, nawet jeśli chodzi tylko i wyłącznie o bardzo krótką perspektywę czasu. Stąd też, próbując zastosować proces indukcji, można poszukać szczegółowego przykładu, który pozwoliłby lepiej zrozumieć następstwa Arabskiej Wiosny w ujęciu całościowym. Krwawa wojna domowa w Syrii, możliwość upadku obecnego niestabilnego reżimu w Egipcie i Tunezji, a także pytania o przyszłość powojennej Libii, przysłoniły w pewnym sensie problemy położonego w strategicznie ważnym regionie Zatoki Adeńskiej Jemenu. Jednak to być może właśnie krytyczna analiza obecnej sytuacji na płaszczyźnie jemeńskiej, może dostarczyć wielu wniosków, co do potencjalnych dróg wykorzystania szans płynących z Arabskiej Wiosny lub wskazania przyczyn zaprzepaszczenia jej pozytywnego dorobku.

Wiele skomplikowanych czynników, które współcześnie nakładają się na sytuację w Jemenie, wskazuje na to, że to biedne państwo, może stać się swego rodzaju poligonem doświadczalnym dla całego regionu. Stąd też tak ważną rolę spełnia dogłębna analiza wydarzeń w Jemenie po 2011 r., kiedy to w wyniku zarówno pokojowych protestów, jak i starć zbrojnych, zmuszony do opuszczenia stanowiska prezydenta został wieloletni przywódca Ali Abdullah Saleh. Niniejsza analiza zbudowana została w taki sposób, aby zaprezentować zarys najważniejszych problemów występujących przed newralgicznym 2011 r., ukazać przebieg rewolucji w Jemenie w trakcie trwania Arabskiej Wiosny, a następnie nakreślić główne kierunki zmian mających miejsce w 2012 r. wraz ze wskazaniem podejmowanych współcześnie prób wyjścia ze stanu permanentnego kryzysu w tym państwie.

\section{Jemen - państwo permanentnej niestabilności}

Republika Jemenu - Al Jumhuriyah al Yamaniyah (CIA Factbook) jest państwem bardzo niestabilnym oraz podatnym na różnego rodzaju wewnętrzne turbulencje niemal od samego początku powstania (Whitaker, 2009). Przyczyny problemów ulokowane są w historii tego państwa, będąc pokłosiem kwestii religijnych, ideologicznych, walki o władzę pomiędzy samymi Jemeńczykami, a także doświadczania ingerencji innych państw w sprawy wewnętrzne. Z kwestii nie poddanych dalszemu omówieniu w niniejszym artykule, ale nadal oddziaływujących na realia w polityce jemeńskiej, należy wskazać m.in. brytyjską obecność w Adenie (Hinchcliffe, Ducker, Holt, 2006) częstokroć określanym jako Jemen Południowy, wojnę domową w Jemenie Północnym, która rozgorzała w latach 60. XX w. czy też późniejszą interwencję Egipską w Jemenie (Kubiak, 2010). Jednocześnie do najważniejszych, bezpośrednich przyczyn niestabilności, poprzedzających Arabską Wiosnę w Republice Jemenu zaliczyć można: rozbicie wewnętrzne państwa, dzielące republikę na tzw. północ i południe, które wytyczone zostało zgodnie z dawnym podziałem na dwa państwa jemeńskie; niezdolność władzy centralnej do pełnej kontroli terytorium państwa i wymóg współpracy z lokalnymi klanami; potrzebę walki, ale również negocjacji pokojowych w celu rozwiązania problemu rewolty Huti przy granicy z Arabią Saudyjską (Hiltermann, 2009; Salmoni, Loidolt, Wells 2010); słabość niedemokratycznego reżimu, skonstruowanego przez zwolenników byłego prezydenta Ali 
Abdullaha Saleha, który opierał się przez lata na dominacji jednej struktury politycznej, niemal w całości zawłaszczającej państwo; gwałtowny rozwój islamskich organizacji terrorystycznych oraz rozszerzenie na terytorium Jemenu wojny z terroryzmem.

\section{Wybrane przyczyny słabości państwowości jemeńskiej}

W trakcie całego XX w. trudno mówić o zjednoczonym oraz przede wszystkim jednym, na trwałe zunifikowanym państwie, obejmującym całe terytorium Republiki Jemenu. Najprostszym, jednak aktualnym podziałem historycznym, wpływającym bezpośrednio na jemeńską państwowość, jest rozróżnienie na tzw. Jemen Południowy oraz Północny (dawne Ludowo-Demokratyczna Republika Jemenu oraz Jemeńska Republika Arabska). Obie części, obecnie już formalnie zjednoczonej Republiki Jemenu (Al Jumhuriyah al Yamaniyah), dysponują własną historią oraz doświadczeniami z zakresu rozwiązań ustrojowych. Ich zjednoczenie było procesem długotrwałym oraz niezwykle skomplikowanym, które de iure zakończyło się dopiero 22 maja 1990 r. (Gruszczak, 2004, s. 712). Jednak po kilku zaledwie latach zjednoczenia, w maju 1994 r. dawne poludnie zbuntowało się oraz ogłosiło powstanie, nieuznanej przez społeczność międzynarodowa, niepodległej Demokratycznej Republiki Jemenu, ze stolicą w mieście Aden. Przy braku poparcia zewnętrznego próba rewolty okazała się być nieudaną, a siły zbrojne z północy brutalnie zdławiły wszelki opór. Późniejsza wojskowa pacyfikacja terytoriów objętych walkami na trwałe wpisały się $\mathrm{w}$ samoświadomość pokrzywdzonych mieszkańców. Głównym zarzutem wystosowanym przez mieszkających na południu względem władz w Sanaa było wykorzystywanie ich przez, niejako sztucznie narzucone elity polityczno-gospodarcze, wywodzące się z północy i pozostające w sojuszu z obozem prezydenta A. A. Saleha. Dla wielu mieszkańców południa Jemenu to właśnie wojna z 1994 r. stanowi nadal główny polityczny punkt odniesienia, który determinuje ich postawy względem przyszłości całego państwa. Najbardziej radykalni z tzw. poludniowców podkreślają że obecna państwowość jest niczym innym jak tylko formą zniewolenia przez rządzących z północnych części Jemenu. To właśnie obywatele zamieszkujący południe państwa należeli przez lata do najbardziej aktywnej opozycji względem, wieloletniego, byłego już prezydenta, A. A. Saleha (Alley, al-Iryani, 2009). Wielu przedstawicieli tzw. Ruchu Południa (al-Hirak), które powstało de facto w miejsce najsilniejszej partii dawnego Jemenu Południowego, zostało zmuszonych do wyjazdu z państwa. Ich powrót był jednocześnie możliwy dopiero po upadku A. A. Saleha w obliczu Arabskiej Wiosny. Głównym celem politycznym Ruchu Południa było od początku ustanowienie swoistej autonomii na terytorium dawnego Jemenu Południowego (Lackner, 2012).

Poza historycznym rozłamem państwa na linii północ-południe, Republika Jemenu musiała radzić sobie również z kwestią braku kontroli rządu centralnego nad pewnymi, wydzielonymi regionami państwa (Koehler-Derrick, 2011), zarządzanymi przez plemiona oraz klany. Terytoria zarządzane bezpośrednio przez najważniejsze jemeńskie klany wpisują się w tradycję państwowości jemeńskiej, a ich rozmieszczenie obejmowało obszary w różnych częściach republiki, łącznie ze strategicznymi rejonami bliskimi stołecznej Sanaa. Rola klanów, chociaż co należy podkreślić nie jest decydująca w polityce państwa, to jednak stanowi jeden z ważnych czynników w całościowym rozkładzie sił na 
jemeńskiej scenie politycznej na przełomie XX/XXI w. (Schmitz, 2011). Szczególnie $\mathrm{w}$ trakcie rządów prezydenta A. A. Saleha, wspomniane organizacje klanowe, wpisały się na trwałe jako narzędzie w dążeniu do utrzymania władzy w całym państwie przez ówczesny reżim. Prezydent oraz jego obóz wykorzystał pierwotne struktury klanowe (Weir, 2007; Dresch, 1989), składające się zarówno z własnych rad, zgromadzeń, sądów, szejków, ale także różnego rodzaju uzbrojonych milicji, posłusznych przywódcom regionalnym, poddając je szeroko zakrojonym procesom korupcyjnym. Do $2011 \mathrm{r}$. władza centralna ulokowana w Sanaa, niejednokrotnie bezpośrednio z budżetu państwa, opłacała różnych szejków oraz podlegające im struktury klanowe, uzyskując ich poparcie. Opłacanie liderów klanowych miało dwa cele, pierwszym z nich było systematyczne utrwalenie pozycji sojuszników rządzących, a drugim rzeczywiste ograniczanie wpływów rosnącej w siłę opozycji, występującej przeciwko reżimowi A. A. Saleha. Należy podkreślić, że jemeńskie klany nie prezentuja jednolitego, wspólnego stanowiska, co sprzyja ich rozgrywaniu przez poszczególne strony w walce o władzę nawet po Arabskiej Wiośnie. Niejednokrotnie także sami prominentni przywódcy klanowi dążą do uzyskania znaczącej pozycji politycznej w skali całego państwa. W tym celu owi liderzy klanowi posługują się różnego rodzaju tzw. konfederacjami klanów, do których zaliczają się współcześnie najbardziej wpływowe Bakil i Hashid. Wyróżnikiem pozycji klanów w polityce jemeńskiej jest również ich geograficzne rozmieszczenie. Przyjmuje się, że istnieją istotne różnice pomiędzy klanami północnymi oraz południowymi. Te pierwsze charakteryzuje dążenie do realnego oddziaływania i wpływania na politykę całego Jemenu prowadzoną w Sanaa, zaś drugie są w większym stopniu skupione na kwestiach wewnętrznych i zapewnieniu swojej ludności bezpieczeństwa m.in. w obliczu wzrostu zagrożenia ze strony różnych organizacji terrorystycznych.

Problemem destabilizującym nie tylko sytuację w samym Jemenie, ale rozlewającym się daleko poza jego granice jest tzw. rewolta Huti (Zimmerman, Harnisch, 2010). Ognisko zapalne zlokalizowane jest $\mathrm{w}$ głównej mierze $\mathrm{w}$ rejonach ulokowanych na granicy z Arabią Saudyjską, obejmując realny spór na płaszczyźnie polityczno-religijnej na terytorium obu państw arabskich. Przedstawiciele ruchu Huti, sama nazwa pochodzi od zabitego przez wojska jemeńskie lidera polityczno-religijnego Badra Edina al-Huti, to ruch reprezentujący zajadytów, czyli wyznawców odłamu szyickiego islamu, najbardziej zbliżonego do jego sunnickiej wersji (Zimmerman, Harnisch, 2010). Z racji swoich przekonań religijnych zajadyci są brutalnie represjonowani zarówno w sunnickiej Arabii Saudyjskiej, jak i w Jemenie. Od pewnego czasu Huti otrzymują, według różnych źródeł, nieoficjalne wsparcie ze strony szyickiego Iranu (Schmitt, Worth, 2012; Shamlan, 2012; Kumar Pradhan 2009). W listopadzie 1918 r. do władzy w Jemenie Północnym doszła konserwatywna zajdycka dynastia Hamid al-Din. Początki dynastii siegają jeszcze $1891 \mathrm{r}$. Po 1918 r., aż do wybuchu rewolucji w 1962 r., rządziło dwóch jej przedstawicieli - imamowie Yahya ibn Muhammad Hamid al-Din i jego syn Ahmad (Mattar, 2004, s. 2390; Phillips, 2008, s. 43-44). Od momentu obalenia imamatu w Jemenie zajadyci utracili znaczne wpływy polityczne, a przede wszystkim znajdowali się w sporze z głównym nurtem polityki nowego państwa. Jednak w polityce wewnętrznej Jemenu zajadyci, skupieni przede wszystkim wokół miasta Sa'ada w prowincji Saada, nadal stanowią ważną siłę polityczną. Obecnie zwolennicy i bojownicy należący do ruchu Huti, jako cel własnych działań postawili sobie obronę własnych wpływów politycznych wśród wszystkich zajdytów oraz wywieranie większej presji politycznej na politykę całego państwa m.in. 
w kontekście walki z prześladowaniem ich współwyznawców. Przełomem w rozwoju ruchu Huti była inwazja na Irak w 2003 r., wówczas w prowincji Sa'ada wybuchły zamieszki przeciwników polityki A. A. Saleha, uznawanego za sprzymierzeńca Stanów Zjednoczonych. Po zabiciu Badra Badra Edina al-Huti, na czele rewolty w Sa'ada (Saada, 2008) stanął jego syn Abdul-Malik Huti, liderujący formacji Al-Shabab al-Muamin (Al-Houthi, 2008). Obecność zrewoltowanych zajadytów z ruchu Huti zmuszała władze jemeńskie nie tylko do dyslokacji znacznych sił wojskowych w regionie, ale również do negocjacji z państwami trzecimi - w głównej mierze z granicząca z Jemenem Arabią Saudyjską, która w następnych latach była oskarżana m.in. o zaatakowanie baz Huti na terytorium Jemenu (Saudi, 2009). Pomimo faktu, że w 2007 r. podpisano zawieszenie broni, a rok później zawarto oficjalne porozumienie pokojowe w prowincji, rejon pozostawał niestabilny. W trakcie walk z wojskami jemeńskimi jednostki Al-Shabab al-Muamin poniosły znaczne straty, jednak nadal były i są aktywne w prowincji, a relacje w Sa'ada pomiędzy rządem i dawnymi rebeliantami, w przededniu rewolucji z 2011 r., pozostawały dalekie od ostatecznego uregulowania. Zaś aktywność irańska pozwala przypuszczać, że region nadal będzie punktem zapalnym na granicy saudyjsko-jemeńskiej (Atarodi, 2010, s. 36).

Na permanentny stan kryzysu w Jemenie bezpośredni wpływ miały również rządy wieloletniego prezydenta A. A. Saleha oraz charakter struktury władzy w państwie, powstały w wyniku rządów jego rodziny i politycznych sojuszników (Phillips, 2008). Jemeński system polityczny, przed Arabską Wiosną, opierał się na fasadowych instytucjach demokratycznych, ale w praktyce przypominał formy autorytarne znane z innych państw tego regionu. Podstawą władzy była quasi partia-ruch władzy w postaci Powszechnego Kongresu Ludowego, powstałego jeszcze w 1982 r., to jest w okresie funkcjonowania Jemeńskiej Republiki Arabskiej. Pomimo odniesień do nacjonalizmu arabskiego, Kongres nie został zbudowany w oparciu o jakąś konkretną ideologię czy jasno zdefiniowany program polityczny. Niemal od samego założenia miała to być organizacja mająca na celu tylko i wyłącznie zagwarantowanie utrzymania władzy w państwie dla A. A. Saleha oraz jego politycznych współpracowników. Jemeńska partia władzy przejęła najważniejsze stanowiska w państwie, czerpiąc zyski z wręcz zinstytucjonalizowanej korupcji, a nepotyzm był widoczny w wielu kluczowych sektorach funkcjonowania Jemenu. Najbardziej strategiczne dla reżimu stanowiska w państwie obsadzone zostały przy tym bezpośrednio przez rodzinę prezydenta oraz jego najwierniejszych sojuszników. Partie opozycyjne były prześladowane, chociaż skala prześladowań nie przypominała np. Egiptu. Przede wszystkim rozbijano jedność jakiejkolwiek opozycji poprzez korumpowanie poszczególnych liderów i rozgrywanie poszczególnych interesów różnych stronnictw przeciwko sobie. Jemeńskie wybory dalekie były od standardów demokratycznych, manipulowano także przy terminach przeprowadzenia poszczególnych elekcji, przesuwając je niejako zgodnie z wolą prezydenta A. A. Saleha. Zawłaszczenie państwa oraz jego polityczne rozbicie wpłynęło na ogólną słabość ekonomiczną Jemenu. Oprócz biedy, największej wśród państw arabskich, w państwie szerzył się również analfabetyzm, a ludność nie miała odpowiedniego dostępu do opieki zdrowotnej czy podstawowych świadczeń socjalnych.

Jednak ani problemy gospodarcze, ani charakter reżimu A. A. Saleha nie były postrzegane przez społeczność międzynarodową jako odpowiednie kwestie wymagające zwrócenia uwagi na Jemen. Stało się to dopiero wraz z ukazaniem problematyki jemeńskiej przez pryzmat terroryzmu. Symbolem stały się wydarzenia z 2000 r., kiedy to okręt wo- 
jenny US Navy, niszczyciel USS Cole, został zaatakowany przez terrorystów samobójców w porcie adeńskim (Perl, O’Rourke, 2001). Śmierć poniosło, aż siedemnastu Amerykanów, a trzydziestu dziewięciu członków załogi odniosło liczne obrażenia. Sam nowoczesny okręt, gdyby nie heroiczna postawa członków załogi, uległby zatopieniu. To wówczas, już na rok przed zamachami z 11 września 2001 r., okazało się jasne dla władz amerykańskich, że Jemen od dawna znalazł się w orbicie zainteresowań międzynarodowych organizacji terrorystycznych, które rozwinęły tam swoje siatki oraz bazy. Wymusiło to bezpośrednio reakcję ze strony Stanów Zjednoczonych, szczególnie, że w trakcie późniejszych śledztw okazało się, iż w Jemenie funkcjonują od lat sprawnie działające struktury terrorystyczne, podobne do tych, które odpowiadały chociażby za wcześniejsze zamachy na placówki dyplomatyczne w Kenii i Tanzanii w 1998 r. Stąd też to właśnie Jemen, obok strategicznie ważnej kampanii w Afganistanie, stał się de facto kluczowym frontem wojny z globalnym terroryzmem w trakcie administracji Georga W. Busha jr. (Popp, 2010). Od zamachów z 11 września, ówczesny jemeński prezydent, A. A. Saleh stanął po stronie Stanów Zjednoczonych i uznał się za sojusznika Ameryki. Dzięki czemu władze amerykańskie udzieliły mu pomocy w celu zwalczania organizacji terrorystycznych, działających na terytorium Jemenu. Amerykańskie fundusze zasiliły różne programy rządowe, a część elitarnych jednostek była szkolona przez amerykańskich instruktorów. Jednocześnie to Jemen obok Pakistanu stał się w późniejszym czasie polem kampanii lotniczej z użyciem bojowych bezzałogowych statków powietrznych (bsp), a najsłynniejszym dotychczas atakiem z użyciem bsp w Jemenie było zabicie słynnego terrorysty Anwara al-Awlakiego (Griffin, Fishel, 2011; Anwar, 2011). Należy przy tym wskazać, że zachodnie wsparcie reżimu A. A. Saleha zostało zaabsorbowane przede wszystkim przez jemeńskie władze w celu umocnienia własnej władzy, a realnie to islamskie organizacje terrorystyczne zyskały najwięcej na tym sojuszu. Przede wszystkim doszło do nawiązania współpracy różnych komórek terrorystycznych pod jednym, wspólnym szyldem Al-Kaidy w Jemenie. Ukazaniem siły ówczesnej Al-Kaidy było zorganizowanie w 2006 r. ucieczki, aż dwudziestu trzech terrorystów, z pilnie strzeżonego więzienia w Sanaa. W 2009 r. jemeńscy terroryści, utożsamiający się z Al-Kaidą, ogłosili swoje zjednoczenie z podobnymi grupami terrorystycznymi z Arabii Saudyjskiej, tworząc obecną Al-Kaidę Półwyspu Arabskiego (Al-Qa'ida, 2013). Od tego czasu terroryści jemeńscy stali się jednymi z najgroźniejszych na świecie, szczególnie po osłabieniu Al-Kaidy w innych regionach świata, to oni byli w stanie organizować zamachy zarówno na terytorium Jemenu, ale również poza nim. Apogeum bezpośrednich działań Al-Kaidy Półwyspu Arabskiego przypadło na okres poprzedzający upadek reżimu A. A. Saleha w 2011 r., kiedy to formacje należące do jemeńskiej struktury tzw. Ansar al Shariah, najprawdopodobniej organizacji fasadowej Al-Kaidy Półwyspu Arabskiego, opanowały znaczne terytoria prowincji Abyan wraz z miastem Jaar (Gordon, 2012). Islamiści okrążyli i prowadzili wówczas zacięte walki o samą stolicę prowincji Zinjibar.

\section{Polityczne zmiany w przededniu Arabskiej Wiosny}

Podstawy pod przemiany polityczne w Jemenie z 2011 r. zapoczątkowane zostały niejako już na początku XXI w. Znaczącym impulsem było wyłonienie się, względem 
A. A. Saleha, jednej opozycyjnej siły w postaci jemeńskiego Zjednoczonego Zgromadzenia Partii. Było to istotne dla późniejszych wydarzeń, gdyż pojawiła się prawdziwa polityczna alternatywa ogólnopaństwowa, mogąca skanalizować politycznie opór przeciwko Salehowi ze strony różnych, niejednokrotnie wcześniej poróżnionych ze sobą grup. Należy podkreślić, że całe zarządzanie Jemenem ówczesny prezydent oraz jego sojusznicy, opierali na dywersyfikacji władzy pomiędzy różne ośrodki w państwie, a także sprawnie prowadzonej grze interesów pomiędzy prominentnymi członkami Powszechnego Kongresu Ludowego, dowódcami wojskowymi, liderami klanów. Ważne było również swoiste rozgrywanie przeciwko sobie istniejących partii opozycyjnych. Inicjatywa Zjednoczonego Zgromadzenia Partii opierała się na nawiązaniu współpracy pomiędzy Jemeńską Partią Socjalistyczną (jedną z dawnych głównych partii Jemenu, wywodzącą się z Jemenu Południowego), partią Hizb Al-Haq, Partią Unionistyczną Nasseryzmu, partią Zjednoczenia Sił Ludowych, a od 2005 r. również wpływowym Jemeńskim Zgromadzeniem na rzecz Reform (Islah), wspieranym przez różne ruchy religijne. Już w wyborach parlamentarnych w 2006 r. nowa, zjednoczona opozycja uzyskała bardzo dobry wynik, w przyszłości zagrażający dotychczasowej supremacji Powszechnego Kongresu Ludowego. Jednak reżim na czele z prezydentem A. A. Salehem wstrzymali wszystkie prodemokratyczne działania. Stąd też po fiasku pokojowych inicjatyw od 2006 r. cały czas dochodziło również do protestów ulicznych wymierzonych w politykę władz jemeńskich. Zjednoczenie się szerokiej opozycji oraz wystapienia ludności sprzyjały w głównej mierze zwiększeniu się samoświadomości obywatelskiej w Jemenie. Do 2009 r. protest przybierały w głównej mierze pokojowy charakter, a ich szczególne nasycenie miało miejsce na już naturalnie niestabilnym południu państwa (Longley Alley, A. Ghani al-Iryani, 2009). Przełomowe okazały się lata 2009-2010, które przyniosły dalszą destabilizację sytuacji wewnętrznej w Jemenie, zarówno w sferze politycznej, jak i bezpieczeństwa wewnętrznego, implikując narastanie dalszych niepokojów społecznych. Chociaż w przededniu Arabskiej Wiosny pozycja A. A. Saleha i dotychczas wspierającego jego rządy układu sił politycznych, widocznie nie uległa pogorszeniu i nie było oznak, że jego niemal trzydziestotrzyletnie rządy zbliżają się do końca.

\section{Arabska Wiosna w Jemenie}

Fala społecznych rewolucji, wybuchających w całym regionie MENA dotknęła także niestabilnego wewnętrznie Jemenu. Już w połowie stycznia 2011 r. tysiące Jemeńczyków, po raz pierwszy w okresie rewolucji, wyszło na ulice stołecznej Sanaa oraz innych miast, znajdujących się przede wszystkim na południu państwa. Protesty miały wymiar antyprezydencki, a podstawowymi hasłami jednoczącymi ludzi w nich uczestniczących było natychmiastowe ustapienie A. A. Saleha oraz przeprowadzenie następnie demokratycznych zmian w systemie politycznym państwa. Zaskoczony skalą protestów prezydent oraz jego doradcy, podobnie jak to miało miejsce w Tunezji czy też Egipcie, odpowiedzieli użyciem służb bezpieczeństwa, które zatrzymywały liderów protestu. Jednak same aresztowanie najbardziej wpływowych liderów zgromadzeń ulicznych, m.in. Tawakul Karman (Finn, Yemen, 2011), nie przyniosło zamierzonego skutku, a raczej wywołało kolejne spontaniczne demonstracje. Jednocześnie do dotychczasowych opo- 
zycjonistów przyłączały się osoby dotychczas niezaangażowane w protesty, które chciały pokazać w taki sposób swój sprzeciw wobec kierunku rządów ówczesnej administracji w Sanaa (Finn, Yemenis, 2011). Na początku lutego 2011 r., w obliczu kolejnych i nie mogących być spacyfikowanymi, fal protestów ulicznych A. A. Saleh wystąpił po raz pierwszy z propozycją ugody politycznej, zakładającej jego ustapienie z piastowania urzędu prezydenta w 2013 r., a także wdrożenie szerokiej reformy systemu wyborczego. Przy czym A. A. Saleh miał zagwarantować, że po ustapieniu nie przekaże władzy swojemu synowi. Rosnąca w siłę opozycja nie przyjęła jednak propozycji ze strony ówczesnego prezydenta, traktując je jako deklaratywne ustęstwa, obliczone na wygaszenie nastrojów rewolucyjnych w państwie. Miało to odbicie w fakcie, że wydarzenia międzynarodowe coraz mocniej potęgowały ferment nie tylko w samym Jemenie, ale w całym regionie. Po próbie stabilizacji sytuacji w państwie przez ustępstwa polityczne, obóz rządzący odwołał się do zwolenników A. A. Saleha. W stołecznej Sanaa, władze zmobilizowały własne grupy protestujących, jednocześnie nasilając akcje służb bezpieczeństwa i dokonując kolejnych zatrzymań wśród grona opozycjonistów. Próbując zdyskredytować głównych liderów demonstracji, ówczesny prezydent, oskarżył swoich przeciwników politycznych o współpracę z Izraelem oraz Stanami Zjednoczonymi, a oba państwa o bezpośrednie inspirowanie wystapień antyrządowych w całym świecie arabskim (Yemen leader, 2011; Yemen's President, 2011). Kryzys jemeński zmienił swoje oblicze wraz z wydarzeniami z 18 marca $2011 \mathrm{r}$. W trakcie szerokiej akcji protestów wymierzonych w A. A. Saleha, określanych jako tzw. piqtek godności, nieznani snajperzy ulokowani w Sanaa zabili ok. 50 bezbronnych demonstrantów, a ponad 200 kolejnych ranili (Yemen imposes, 2011). W obliczu wydarzeń prezydent A. A. Saleh ogłosił w państwie mający trwać miesiąc stan wyjątkowy, ale sytuacja zaczęła przypominać początki wojny domowej. Do jeszcze bardziej krwawych niż te z Sanaa, ale medialnie mniej znanych, ataków ze strony sił reżimowych na bezbronnych protestujących doszło później w mieście Ta'izz. Właśnie tam 29 maja $2011 \mathrm{r}$. czołgi oraz buldożery zostały użyte do rozbicia miasteczka namiotowego opozycji. Wraz z zaognieniem się sytuacji wewnętrznej oraz użyciem siły przeciwko demonstrantom kluczowa okazuje się być przyszła postawa jemeńskich sił zbrojnych, a także licznych, uzbrojonych formacji milicji podległych jemeńskim klanom. Przede wszystkim 21 marca 2011 r. część dowódców wojskowych ogłasza swoje poparcie dla protestujących i zapowiada, że będą chronili obywateli. Szczególną rolę odegrała wówczas postawa generała Ali Mohsen al-Ahmar, dowódcy Pierwszej Dywizji Zmechanizowanej. A. Mohsen al-Ahmar, był długoletnim sojusznikiem A. A. Saleha, ale w 2011 r. opuścił prezydenta, twierdząc że podlegli mu żołnierze będą czuwali nad bezpieczeństwem protestujących (Hatem, 2011). Postawa generała od razu sugerowała, że dąży on do wzmocnienia własnej pozycji politycznej, a być może nawet do przejęcia władzy po możliwym upadku reżimu. Oprócz wcześniejszej dobrej znajomości z A. A. Salehem, A. Mohsen Al-Ahmar miał niewyjaśnione do końca związki z salafickimi organizacjami terrorystycznymi działającymi w Jemenie. Oprócz ok. 20 tysięcy własnych żołnierzy gen. Ali Mohsen stanął na czele formacji milicji z klanów, które wsparły protestujących. Jemen pogrążył się w chaosie niewypowiedzianej wojny domowej, toczonej na ulicach pomiędzy stronnikami prezydenta oraz opozycją domagającą się jego ustapienia. W kwietniu 2011 r., po rozmowach z przywódcami coraz aktywniejszej w obliczu kryzysu, Arabii Saudyjskiej, prezydent A. A. Saleh po raz pierwszy oficjalnie wspomina 
o możliwości ustąpienia ze stanowiska już wraz z końcem 2011 r. oraz raz jeszcze zapowiada możliwość przeprowadzenia kluczowych reform w systemie politycznym państwa (Finn, Al-Harazi, 2011). Jednakże rosnący w siłę protestujący odrzucają każdorazowo kolejne propozycje, dążąc do jak najszybszego i bezwarunkowego obalenia znienawidzonego A. A. Saleh. Szczególnie, że obóz rządzący po wydarzeniach z 18 marca utracił poparcie wśród wielu dotychczas wpływowych sojuszników, m.in. w kręgach elity religijnej państwa. Jemen stanął wówczas na krawędzi upadku, podobnie jak to miało miejsce w przypadku Somalii na początku lat 90 . XX w. A. A. Saleh nawet przy użyciu wszystkich sił, na czele z wierną mu Gwardią Republikańska, nie był w stanie przywrócić porządku w państwie, a opozycja nie była w stanie pozbawić go tej władzy. Podobnie jak w przypadku sił zbrojnych doszło również do podziałów wśród dotychczas wspierających A. A. Saleha klanów z północnego Jemenu. W marcu konfederacja Hashid, na czele z wpływowym szejkiem Sadeqiem al-Ahmar udzieliła swego wsparcia opozycji. Przede wszystkim motywem, pragmatycznych, działan rodziny al-Ahmar (Who's, 2011) była chęć uzyskania jeszcze szerszych wpływów w całym państwie. Przedstawiciele al-Ahmar zdawali sobie sprawę, że mogą uzyskać potencjalne wsparcie ze strony sąsiedniej Arabii Saudyjskiej, która jako jedyna mogła wymusić ustąpienie A. A. Saleha. Część milicji klanowych wręcz uderzyła w kierunku stołecznego miasta Sanaa, ale po walkach z wiernymi prezydentowi jednostkami wojskowymi została odrzucona. Jednocześnie duża część formacji klanowych pozostała nadal wierna A. A. Salehowi, co leżało u podstaw wybuchu ok. 24 maja 2011 r. walk już pomiędzy samymi różnymi frakcjami wśród klanów z północnych części państwa.

Prezydent A. A. Saleh, nawet pod groźbą eskalacji konfliktu, nie ustąpił ze swojego stanowiska, a bezpośrednim wsparciem dla jego działań jest budowana od lat sieć sojuszników w aparacie oraz służbach państwa. Jego syn Ahmed, był dowódcą elitarnych formacji Gwardii Republikańskiej, zaś inni bliżsi lub dalsi krewni odpowiadali za służby wywiadowcze i kontrwywiadowcze państwa, dowodzili również jemeńskimi jednostkami sił operacji specjalnych, które przeszły wyjątkowe szkolenie prowadzone przez amerykańskich doradców wojskowych (Sharp, 2011, s. 8-9). Jemen jest polem protestów ulicznych, walk z użyciem broni lekkiej, a także uaktywnieniem się różnych grup terrorystycznych. 3 czerwca 2011 r., w wyniku niewyjaśnionego do końca ataku rakietowego, którego celem był kompleks budynków rządowych poważnie rannym został sam prezydent A. A. Saleh (Yemen: President, 2011). Jego obrażenia zmuszają go do wyjazdu z Jemenu w celu uzyskania odpowiedniej pomocy lekarskiej w Arabii Saudyjskiej. Na scenie politycznej pojawił się wówczas, pełniący obowiązki prezydenta, dotychczasowy wiceprezydent Abdo Rabu Mansour Hadi. Pod nieobecność A. A. Saleha w państwie dochodziło do dalszych starć pomiędzy bojówkami obu stron politycznego konfliktu. Jednak decydujące okazały się zabieg dyplomatyczne prowadzone pod patronatem Arabii Saudyjskiej oraz Rady Współpracy Zatoki (GCC), przy wsparciu ze strony ONZ, Stanów Zjednoczonych oraz Unii Europejskiej. Ich finałem było podpisanie przez A. A. Saleha planu pokojowej transformacji władzy i ostatecznego zakończenia okresu rządów dotychczasowego prezydenta Jemenu. Porozumienie zostało podpisane w Rijadzie, w pałacu należącym do saudyjskiego monarchy Abdullaha, gdzie spotkali się przedstawiciele dotychczasowych zwaśnionych stron jemeńskiego konfliktu i specjalny przedstawiciel ONZ ds. Jemenu Jamal bin Omar (Rashad, 2011). Strony doszły do porozumienia w za- 
kresie przekazania przez A. A. Saleha całej władzy maksymalnie do początku lutego 2012 r., a 90 dni od podpisania układu miały zostać przeprowadzone nowe wybory prezydenckie, w których wspólnym kandydatem byłby, dotychczasowy wiceprezydent i p.o. prezydenta w okresie leczenia w Arabii Saudyjskiej A. A. Saleha, A. R. Mansour Hadi. Jednocześnie 14 dni po podpisaniu układu miał zostać sformowany nowy rząd jedności narodowej, a misję tworzenia powierzono również A. R. Mansourowi Hadi. Ten sam polityk został zobligowany do stanięcia na czele tymczasowej rady bezpieczeństwa, która miała zająć się zapewnieniem spokoju w państwie. W głównej mierze wymagane było ustabilizowanie sytuacji w stołecznej Sanaa, rozdartej dotychczas na dzielnice kontrolowane przez różnego rodzaju bojówki. A. R. Mansour Hadi miał również zaproponować reformy konstytucyjne, zakładające odejście od dotychczasowego systemu prezydenckiego, a rozszerzające kompetencje nowego bikameralnego parlamentu (Yemen crisis, 2011). Największe obawy co do przyszłej implementacji porozumień z Rijadu budziło pozostawienie A. A. Saleha oraz jego stronników bez jakiegokolwiek osądzenia za działania w trakcie Arabskiej Wiosny. Niepewną kwestią było również pozostawienie wielu wpływowych stronników ustępującego prezydenta w resortach siłowych państwa. Pomimo obaw rewolucja jemeńska przyniosła wiele optymizmu nie tylko samym Jemeńczykom, ale również społeczności międzynarodowej. Jemen w przeciwieństwie do Libii oraz Syrii nie pogrążył się w wojnie domowej, a powrót władzy centralnej rodził nadzieję na skuteczną rozprawę z terrorystami wykorzystującymi dotychczasowy chaos w państwie. Jednocześnie wybór A. R. Mansoura Hadi na wspólnego kandydata oraz pozostawienie na wolności A. A. Saleha stwarzał warunki do rzeczywistego ogólnonarodowego porozumienia.

\section{Rok 2012 - pierwsze działania nowej władzy}

Pod koniec 2011 r. rozpoczął się proces mający na celu pełną implementację założeń porozumienia z Rijadu. Na premiera tymczasowego rządu jedności narodowej A. R. Mansour Hadi mianował dotychczasowego wpływowego opozycjonistę Mohammeda Basindwa. Formalnie stał się on następcą Ali Mohammeda Mujawar, którego na początku 2011 r., w obliczu dezercji niektórych ministrów do obozu rewolucjonistów, zdymisjonował A. A. Saleh, przejmując jego dotychczasowe kompetencje (Yemen's vice, 2011). W celu osiagnięcia konsensusu, zjednoczona opozycja ze Zjednoczonego Zgromadzenia Partii przejęła dużą część stanowisk w nowym rządzie, jednak kilka ministerstw (w tym ministerstwo spraw zagranicznych i ministerstwo informacji) pozostało obsadzonych przez ministrów wywodzących się z Powszechnego Kongresu Ludowego (Yemen opposition, 2011). W grudniu 2011 r. gabinet, złożony z 35 ministrów, został ostatecznie zaprezentowany w całości (Yemen forms, 2011). W Sanaa oraz w większych miastach rozpoczęto długotrwałą demobilizację uzbrojonych grup milicji, a także działania mające na celu wyprowadzenie wojska z kluczowych pozycji, które zostały zajęte przez nie w trakcie rewolucji z 2011 r. Odbywało się to w trudnych warunkach, gdyż zwaśnione strony nie chciały pozbywać się atutów w postaci sił mogących wesprzeć zbrojnie ich walkę o władzę w Jemenie. Szczególne problemy stwarzało istnienie różnych ośrodków decyzyjnych w rozbitych wewnętrznie jemeńskich siłach zbrojnych. Kolejnym etapem 
procesu pokojowego miało być przygotowanie państwa do przeprowadzenia nowych wyborów prezydenckich w lutym $2012 \mathrm{r}$. Zgodnie z ustaleniami miały one mieć raczej charakter plebiscytu względem postanowień porozumień pokojowych, albowiem zakładano wystawienie w nich tylko jednego, wspólnego dla dawnego reżimu oraz opozycji kandydata - A. R. Mansoura Hadi (Jamjoom, 2012). 21 lutego 2012 r. przeprowadzone zostały wybory, a frekwencja osiagnęła poziom prawie 60 proc. uprawnionych do głosowania Jemeńczyków (One, 2012). Po oficjalnym wyborze nowego prezydenta państwa, które przebiegło jak na warunki jemeńskie nader spokojnie, nowy przywódca państwa wraz z premierem rządu stanęli przed potrzebą doprowadzenia do stabilizacji oraz unifikacji skłóconego narodu. Temu celowi służyć ma zwołanie, na początku 2013 r., Narodowego Dialogu pod patronatem prezydenta Jemenu. W ramach jego obrad mają zostać poruszone najważniejsze problemy wewnętrzne Jemenu, a w obradach mają wziąć udział przedstawiciele wszystkich ugrupowań politycznych, religijnych oraz etnicznych państwa. Społeczność międzynarodowa, pilnie obserwująca proces pokojowy w Jemenie, uzależniła pomoc finansową dla państwa od sukcesu inicjatywy Dialogu. Należy zaznaczyć, że w trakcie trwania 2012 r. w całym Jemenie bardzo aktywne stały się wszystkie liczące się na jemeńskiej arenie politycznej stronnictwa polityczne i partie. Do państwa wróciło również kilku liderów m.in. z południa, którzy w okresie rządów A. A. Saleha musieli szukać azylu politycznego. Do najbardziej znaczących powrotów zaliczyć trzeba przylot Mohammed Ali Ahmed, historycznego lidera Ruchu Południa (al-Muslimi, 2012). Jednocześnie w 2012 r. prowadzone były zakulisowe działania mające na celu utrzymanie przy stole negocjacyjnym przedstawicieli głównych frakcji ze Zjednoczonego Zgromadzenia Partii, Powszechnego Kongresu Ludowego oraz Ruchu Południa. Przede wszystkim problemem jest po raz kolejny postawa samego A. A. Saleha, który został wskazany jako lider oraz reprezentant Powszechnego Kongresu Ludowego na obrady Dialogu Narodowego (GPC, 2012). Przedstawiciele dawnej opozycji w postaci Zjednoczonego Zgromadzenia Partii traktują taką postawę jako złamanie postanowień pokojowego odejścia A. A. Saleha od władzy oraz grożą nawet bojkotem Dialogu (al-Samei, 2012). Równocześnie problematyczne jest włączenie przedstawicieli południa do rozmów, gdyż ich zdaniem w ramach demokracji pojawiła się szansa dla uzyskania autonomii. Sprzeciwiają się temu m.in. państwa trzecie zaangażowane w pokojowe rozwiązanie rewolucji jemeńskiej $(E U, 2012)$. Niepokojące wydają się być jednak rozłamy w Ruchu Południa (Southern, 2012) na sprzeciwiających się jakimkolwiek rozmowom z północą i bardziej otwartych na dialog w ramach Republiki Jemenu, przez co tym trudniejsze staje się uzyskanie porozumienia oraz zgody ogólnonarodowej.

\section{Przyszlość Jemenu - stabilizacja czy chaos?}

Rok po eksplozji wystąpień w ramach Arabskiej Wiosny, Jemen nadal pozostaje państwem niestabilnym wewnętrznie, z trudną do przewidzenia sytuacją międzynarodową. Jednak po nowych wyborach prezydenckich oraz finalnym ustapieniu A. A. Saleha zauważalne było uzyskanie pewnej dozy współpracy pomiędzy głównymi siłami politycznymi. Przede wszystkim same wybory doszły do skutku i nie zostały zakłócone masowymi atakami lub jakąś formą gwałtownego bojkotu jednej ze stron politycznego 
sporu. Jednocześnie można dokonać pozytywnej oceny działań podejmowanych przez A. R. Mansoura Hadi, który wpisał się w obraz jemeńskiej sceny politycznej. Zauważalna jest również wzmożona aktywność, zarówno ta oficjalna dyplomatyczna, jak i również zakulisowa, ze strony przedstawicieli ONZ, UE oraz Arabii Saudyjskiej. Działania takich dyplomatów jak Jamal bin Omar umożliwiają stworzenie realnej płaszczyzny komunikacji pomiędzy zwaśnionymi stronami, a przy tym wywierają presję na polityków jemeńskich, aby kontynuowali proces rozmów w atmosferze pokojowego dyskursu w ramach demokratycznego państwa. Jednakże rodzą się także realne obawy co do rozpoczęcia przyszłych prac w ramach Dialogu Narodowego, szczególnie po deklaracjach Powszechnego Kongresu Ludowego o wystawieniu A. A. Saleha w roli swojego reprezentanta. Oczywiście trudne do przewidzenia pozostają obecne zakulisowe działania Iranu, szczególnie, że w obliczu napiętej sytuacji związanej z irańskim programem atomowym chaos w Jemenie mógłby stanowić realny problem dla Stanów Zjednoczonych oraz Arabii Saudyjskiej. Wpływ na sytuację w państwie mogą mieć także procesy zachodzące w Somalii, w której rząd tranzycjonalny wraz z siłami należącymi do Unii Afrykańskiej, wypierając terrorystów islamskich, może spowodować ich swoisty exodus właśnie do Jemenu. Niewiadomą są również dalsze działania związane z islamskimi organizacjami terrorystycznymi, które nadal w miarę sprawnie funkcjonują w Jemenie. Stany Zjednoczone, szczególnie w okresie administracji Baracka Obamy, atakując poszczególnych terrorystów z użyciem misji wykonywanych przez uzbrojone bsp są chwalone za skuteczność uderzeń (Watts, Cilluffo, 2012, s. 5-8). Jednak nawet pomimo deklaracji oficjalnych władz Jemenu (Shane, 2012), ataki bsp wywołują niejednokrotnie fale oburzenia ze strony zwykłych Jemeńczyków, a zwiększająca się niechęć do Zachodu sprzyja działaniu organizacji terrorystycznych. Wewnątrz państwa obawy rodzi przede wszystkim kwestia utrzymania przyszłej jedności Republiki Jemenu, w miarę jak coraz otwarciej artykułowane są hasła separatystyczne na południu. Jednocześnie podobny problem, w zakresie utrzymania spójności całego terytorium, dotyczy również regionu wokół miasta Sa'ada z uśpionym problemem zajadytów, a także regionu Hadramout wraz ze stolicą w Mukalla, gdzie pojawił się opór względem rządu centralnego w Sanaa (Seale, 2013). Władze nadal borykają się z kwestią zjednoczenia sił zbrojnych, podzielonych w okresie rewolty z 2011 r. na zwolenników oraz przeciwników A. A. Saleha. Duże znaczenie będzie miała także postawa Zjednoczonego Zgromadzenia Partii względem A. A. Saleha, wobec którego ze strony dawnej opozycji cały czas wysuwane są oskarżenia, nawet pomimo ustaleń z Rijadu gwarantujących bezpieczeństwo prawne. Na przyszłą politykę wpływ będzie miała również kondycja ekonomiczna całego państwa, które boryka się z konsekwencjami kryzysu. Planuje się m.in. reaktywację sektora paliwowego, opierającego się na wydobyciu złóż położonych na terytorium Jemenu, który ucierpiał w latach 2011-2012 (Bafana, 2012). Jednakże najbardziej kluczowym sektorem przemysłu jemeńskiego może stać się przemysł gazowy. Złoża gazu zlokalizowane na terytorium Jemenu byłyby w tym przypadku dopełnieniem potencjalnych gazociąów wiodących z Zatoki Perskiej do specjalnych terminali załadunkowych. Przy czym to właśnie sektor gazowy jest obecnie najczęściej atakowanym elementem przemysłu jemeńskiego, stanowiąc niejako klucz do dalszej stabilizacji państwa. Patrząc z perspektywy roku na wydarzenia w Jemenie należy w głównej mierze podkreślić fakt, że państwo nie pogrążyło się w wojnie domowej, takiej jak ta w Syrii. Sprawne przeprowadzenie ogólnonarodowych wyborów prezydenc- 
kich, stworzenie rządu jedności narodowej, a także próby zbudowania Dialogu Narodowego jako swoistej konstytuanty pod zmiany w całościowym obrazie jemeńskiego systemu politycznego mogą być ukazywane jako wzór dla innych państw ogarniętych Arabską Wiosną. Prawdziwym sprawdzianem staną się właśnie obrady Dialogu w 2013 r., a także potencjalne wybory parlamentarne w 2014 r. Szczególnego znaczenia nabiera również los dawnego prezydenta A. A. Saleha i jego stronników, którzy nie zostali zupełnie wyrugowani z życia politycznego państwa, a tym bardziej osądzeni jak w Egipcie czy też wręcz pozbawieni życia, jak to miało miejsce m.in. w przypadku dyktatora Libii. Jednakże Jemen daleki jest od względnej stabilizacji, a społeczność międzynarodowa nie może zapomnieć o państwie położonym nad Zatoką Adeńską, bowiem wówczas krucha stabilizacja oraz przemiany demokratyczne mogą zostać zaprzepaszczone.

\section{Bibliografia}

Al-Houthi Brothers, Globaljihad.net, http://globaljihad.net/view_page.asp?id=982, 23.01.2013.

Alley L. A., al-Iryani A. G. (2009), Southern Aspirations and Salih's Exasperation: The Looming Threat of Secession in South Yemen, „The Middle East Institute Viewpoints”, No. 11.

al-Muslimi F., Returned South Yemen Leader: 'Peaceful Strugglel May Yet Win (2012), „Al-Monitor”, 11.11., http://www.al-monitor.com/pulse/originals/2012/al-monitor/mohammed-ali-ahmed-former-south.html, 25.01.2013.

Al-Qa'Ida in the Arabian Peninsula, National Counterterrorism Center, http://www.nctc.gov/site/ groups/aqap.html, 20.01.2013.

al-Samei M., JMP to boycott dialogue if Saleh represents the GPC (2012), „Yemen Times”, 27.12., http://www.yementimes.com/en/1637/news/1780/JMP-to-boycott-dialo, 25.01.2013.

Armbruster J. (2012), Arabska wiosna. Rewolucja w świecie islamskim, Wrocław.

Atarodi A. (2010), Yemen in Crisis -Consequences for the Horn of Africa, Sewdish Defence Research Agency, Stockholm.

Bafana H., Dark Days Loom Ahead for Yemen Oil and Gas (2012), „Yemen Times”, 28.05., http://www.yementimes.com/en/1576/report/906/Dark-days-loom-ahead-for-Yemen-oil-and-gas.htm, 25.01.2013.

Dresch P. (1989), Tribes, Government, and History in Yemen, Oxford.

Encyclopedia of the Modern Middle East \& North Africa (2004), red. P. Mattar, New York.

EU ambassador to meet with southern leaders (2012), ,Yemen Post”, 6.11., http://yemenpost.net/ Detail123456789.aspx?ID=3\&SubID=6179, 25.01.2013.

Finn T. (2011), Yemen arrests anti-government activist, „The Guardian”, 23.01., http://www.guardian.co.uk/world/2011/jan/23/yemen-arrests-protest-leader, 19.01.2013.

Finn T., Yemenis take to the streets calling for President Saleh to step down (2011), „The Guardian”, 27.01., http://www.guardian.co.uk/world/2011/jan/27/yemen-protests-president-saleh, 19.01.2013.

Finn T., Al-Harazi S. (2011), Yemeni president vows to step down in 2013 in bid to head off 'day of rage', „The Guardian”, 2.02., http://www.guardian.co.uk/world/2011/feb/02/yemen-president-ali-abdullah-saleh, 13.01.2013.

Gordon S., Abyani Tribes and Al Qaeda in the Arabian Peninsula in Yemen, 7.2012, AEI, „A Report by the Critical Threats Project of the AEI".

GPC assigns Saleh head of delegation to dialogue (2012), „Yemen Fox”, 25.12., http://www.yemenfox.net/news_details.php?sid=5369, 25.01.2013. 
Gruszczak A. (2004), Zjednoczenie Jemenu, w: Historia polityczna świata XX wieku, red. M. Bankowicz, Kraków.

Hatem M. (2011), Yemen Elite Forces Clash With Armored Division Loyal to Al-Ahmar, „Bloomberg”, 14.08., http://www.bloomberg.com/news/2011-08-14/yemen-elite-forces-clash-with-armored-division-loyal-to-al-ahmar.html, 19.01.2013.

Jamjoom M. (2012), Yemen holds residential election with one candidate, 22.02., CNN, http://edition.cnn.com/2012/02/21/world/meast/yemen-elections, 24.01.2013.

Koehler-Derrick G. (2011), A False Foundation? AQAP, Tribes and Ungoverned Spaces in Yemen, The Combating Terrorism Center At West Point.

Kubiak K., Wietnam Egipcjan (1) (2010), „Militarny Magazyn Specjalny Komandos”, No. 5.

Kubiak K., Wietnam Egipcjan (2) (2010), „Militarny Magazyn Specjalny Komandos”, No. 6.

Kumar Pradhan P. (2009), Houthis and external intervention in Yemen, 25.11., Institute for Defence Studies and Analyses, http://www.idsa.in/node/3538/2689, 13.01.2013.

Lackner H. (2012), Yemen: can southern separatists break up Yemen?, „Open Democracy”, No. 23, http://www.opendemocracy.net/helen-lackner/yemen-can-southern-separatists-break-up-yemen, 20.01.2013.

Lynch M. (2012), The Arab Uprising. The Unfinished Revolutions of the New Middle East, New York.

One vote, one man (2012), „The Economist”, 25.02., http://www.economist.com/node/21548292, 25.01.2013.

Phillips S. (2008), Yemen's Democracy Experiment in Regional Perspective. Patronage and Pluralized Authoritarianism, New York.

Rashad M. (2011), Yemen's Saleh signs deal to give up power, Reuters, 23.11., http://www.reuters.com/article/2011/11/23/us-yemen-idUSTRE7AM0D020111123, 20.01.2013.

Saada Shiite Rebels, Globaljihad.net, http://globaljihad.net/view page.asp?id=980, 23.01.2013.

Saudi jets bomb Yemeni Houthis (2009), Al Jazeera, 5.11., http://www.aljazeera.com/news/ middleeast/2009/11/20091151323886933.html, 23.01.2013.

Schmitt E., Worth R. F. (2012), With Arms for Yemen Rebels, Iran Seeks Wider Mideast Role, „New York Times", 15.03., http:/www.nytimes.com/2012/03/15/world/middleeast/aiding-yemen-rebels-iran-seeks-wider-mideast-role.html?pagewanted=all\&_r=0, 13.01.2013.

Seale P. (2013), Yemen Seeks to Talk its Way Out of Chaos, „Yemen Times”, 24.01., http://www.yementimes.com/en/1645/opinion/1900/Yemen-seeks-to-talk-its-way-out-of-chaos.htm, 25.01.2013.

Shamlan A. (2012), Iran helping militant groups in Yemen, „Arab News”, 30.10., http://www.arabnews.com/iran-helping-militant-groups-yemen, 13.01.2013.

Shane S. (2012), Yemen's Leader Praises U.S. Drone Strikes, „The New York Times”, 29.09., http://www.nytimes.com/2012/09/29/world/middleeast/yemens-leader-president-hadi-praises-us-drone-strikes.html? r=0, 25.01.2013.

Sharp J. M. (2011), Yemen: Background and U.S. Relations, CRS Report for Congress, Washington.

Southern leaders meet in Cairo (2012), ,Yemen Post”, 11.11., http://yemenpost.net/Detail123456789.aspx?ID=3\&SubID=6199, 25.01.2013.

The Arab Spring (2011), red. B. Przybylska-Maszner, Poznań.

Watts C., Cilluffo F. J. (2012), Drones in Yemen: Is the U.S. on Target?, HSPI Issue Brief 16, 21.06.

Weir S. (2007), A Tribal Order Politics and Law in the Mountains of Yemen, Austin.

Who's who in Yemen's opposition? (2011), Al Jazeera, 28.02., http://www.aljazeera.com/indepth/spotlight/yemen/2011/02/2011228141453986337.html, 14.01.2013.

Without Glory in Arabia. The British Retreat from Aden (2006), red. P. Hinchcliffe, J. T. Ducker, M. Holt, London. 
Yemen crisis (2011), BBC News Middle East, 23.11., http://www.bbc.co.uk/news/world-middle-east-14988945, 20.01.2013.

Yemen forms new unity government (2011), Al Jazeera, 7.12., http://www.aljazeera.com/news/ middleeast/2011/12/2011127124649367762.html, 24.01.2013.

Yemen imposes state of emergency as 46 shot dead (2011), Al Arabiya News, 18.03., http://www.alarabiya.net/articles/2011/03/18/142070.html, 19.01.2013.

Yemen leader blames protests on US (2011), Al Jazeera, 1.03., http://www.aljazeera.com/news/ middleeast/2011/03/20113191141211328.html, 19.01.2013.

Yemen opposition leader Mohammed Basindwa named prime minister (2011), BBC World Middle East, 27.11., http://www.bbc.co.uk/news/world-middle-east-15912086, 24.01.2013.

Yemen Profile, World Factbook, https:/www.cia.gov/library/publications/the-world-factbook/ geos/ym.html, 20.01.2013.

Yemen: President Saleh injured In attack on palace (2011), BBC News Middle East, 3.06., http://www.bbc.co.uk/news/world-middle-east-13638787, 20.01.2013.

Yemen's President Blames US, Israel for Arab Unrest (2011), Voice of America, 28.02., http://www.voanews.com/content/yemens-president-blames-us-israel-for-arab-unrest-117142538/135793.html, 19.01.2013.

Yemen's vice president names new prime minister (2011), Xinhua, 27.11., http://news.xinhuanet.com/english2010/world/2011-11/28/c 131272989.htm, 24.01.2013.

Zimmerman K., Harnisch C. (2010), Profile: al Houthi Movement, American Enterprise Institute Critical Threats, 28.01., http://www.criticalthreats.org/yemen/profile-al-houthi-movement, 13.01.2013.

\section{Summary}

\section{Yemen - a Forgotten Actor of the Arab Spring}

Modern Yemen is one of the key states in all the geopolitical games in the Middle East. Yet in the comprehensive outlook on the Arab Spring revolutions which spread over the MENA region in 2011, Yemen has been a kind of forgotten actor. The radically increased activity of the AQAP terrorist group, however, coupled with the potential danger of being divided into two or even more independent states, has been a clear impulse for taking a new look at the Yemeni situation following president A. A. Saleh's resignation. First of all, the author of this paper briefly describes the background of the most important historical issues of Yemen and their implications for current political dialogue. Next, how the Arab Spring developed in this poorest Arabic state is shown. Finally, the paper concentrates on the chances and main obstacles in the peaceful transition between the old regime and the new government in 2012 and 2013. It has to be underlined that foreigners especially need to realize the specific nature of the Yemen National Dialogue, because such a path to normalization might be a great solution for all the crises in this permanently unstable region. The potential failure of political agreements will be the first sign of a new, dangerous wave of chaos and the creation of new, large safe havens for terrorists or pirates, as in nearby Somalia.

Key words: Yemen, Saleh, Arab Spring, Sanaa 
